\title{
Development Planning and Dependence
}

\section{José J. Villamil}

\section{Introduction}

Much of development planning theory and practice has been based on neo-classical approaches to development (Lefeber, 1974). This has entailed the use of highly aggregated models, an absence of institutional and political factors in the analysis, an over-emphasis on supply considerations, and the utilisation of universal models to explain specific national experiences. Furthermore, planning has been considered as exogenous to the development model adopted. This article is based on a contrary assumption: planning must be considered as endogenous, recognising that in different development contexts it assumes different functions and definitions.

Recent work on development has questioned traditional neo-classical thinking (as well as that of the 'modernisation' school of sociologists), by placing emphasis on a different set of causal relationships. In particular, the way in which Third World countries have been integrated into the world capitalist system is seen as a determining factor in their present condition. This body of work which, for convenience, we shall call the dependence approach, has entailed a change in the paradigms of development studies. ${ }^{2}$

On the basis of these analytical approaches, development strategies have been proposed which go beyond the more limited objectives of traditional development thinking, related for the most part to income or GNP growth. Included among the objectives are the satisfaction of the basic needs of the population, disengagement from the world capitalist economy, massive redistribution of income and wealth, much greater control by the State of the means of production, and greater collaboration among Third World countries. Before such a strategy can be put into effect, of course, political conditions within a country have to be radically changed so that power is allocated in such a way that it supports these changes. ${ }^{3}$

1 The author wishes to thank members of the Dependence Cluster at the Institute of Development Studies for the many helpful suggestions and comments made on an earlier version of this paper.

2 There is an extensive literature on the dependence approach. For a recent appreciation, see Cardoso, 1977

3 This change could come about as a result of revolution, as in Cuba, or through the electoral process as in Chile in 1970.
This article explores the implications for development planning of adopting such a strategy. Little work exists along these lines, primarily because few dependent countries have actually experienced the change in their political situation which would permit the adoption of such a model.

\section{Underdevelopment and Dependence}

It is important to consider, however briefly, what the dependence approach entails, before dealing with its implications for planning. First, it is not a precisely articulated theoretical model. Although the basic elements of the approach are presented below without qualification, nevertheless dependence thinking places a great deal of emphasis on the particular historical context of national societies. ${ }^{4}$ The development process is no longer seen as the transition between two stages ('traditional' and 'modern', for example), nor as an evolutionary process in which change is continuous and incremental, nor in terms of the 'development-underdevelopment' dichotomy, where the underdeveloped is said to experience a number of gaps vis-à-vis the developed in terms of indicators such as income, industrialisation or urbanisation.

A second element of dependence thinking is that the obstacles to development are not national or internal to a particular society, but rather result from its incorporation into the world capitalist system, with particular structures seen as a consequence of the specific form of incorporation. Development can no longer be regarded as the result of breaking through obstacles such as the low achievement motivation of the population, or resistance to innovation.

A society's social formation and the nature of its dependent relationships are closely interrelated. Although initially some writers of the dependence school took the position that a dependent society's internal organisation was determined by external factors, it is now generally recognised that the nature of the interaction between internal structure and external factors

4 The discussion that follows is merely indicative of some of the major themes that appear in the literature. The dependence approach includes a large number of social scientists with varying perspectives on development problems. Many critics of dependence thinking attribute to it the characteristics of a more coherent, precisely defined theoretical construction. Some focus on the work of one writer, and assume that his work is representative. 
is more complex (Vasconi, 1970). For dependent countries integration into the world capitalist system has meant the formation of a particular type of social and economic organisation which fits the needs of that system, and which has frequently led to the disintegration of national structures. The precise impact of transnational capitalist integration, however, varies with the complexity and stability of a society's structures, and with the manner in which that integration takes place (Sunkel, 1971).

One implication of the dependence view is the need to approach development from a holistic perspective. The problems of development are complex, multi-dimensional ones which cannot be segregated into economic, social, cultural and political compartments. In certain respects the dependence approach is closely related to a systems' view of the development problem. In fact, many of the concepts utilised in systems theory, such as openness, integration and disintegration, are also found in the dependence literature (Gutierrez, Ortiz and Villamil, 1971).

The dependence approach has focused attention on a new set of problems, among them problems related to technological dependence, the impact of communications systems on dependent countries, and the implications of the changing nature of the world capitalist system, particularly the increasing importance of the multinational corporations. It also becomes necessary in this framework to consider the political system as endogenous in dealing with the development process, in contrast to neo-classical approaches where the political system is considered exogenous.

Another important consequence of adopting the dependence approach is the re-definition of development objectives. Our attention is focused on the need to achieve national independence as a primary objective of development and on the concommitant transformation of the mode of production and the class structure. As clearly stated by Vasconi, the modification of a country's dependent condition and the change in its internal structures are parts of the same process, and cannot occur independently of one another (Vasconi, 1970). Some aspects of this transition from dependent capitalist growth to an alternative model which, for convenience, we shall call self-reliant growth, are considered below.

\section{On the transition}

In his book on the transition to socialism, Bettelheim considers two types of transition: one, which he calls a "radical form of transition", between the capitalist mode of production and the socialist; a second, more limited and uncertain type, which characterises those countries moving from colonial to post-colonial status, or from dependence to independence. A number of factors will affect how this latter type of transition will take place: the class nature of the State, whether or not there is a cohesive national bourgeoisie, the prevailing mode of production, and the country's 'room for manoeuvre' (Bettelheim, 1974).

In many ways, the situation under consideration is a hybrid of Bettelheim's two types of transition. We assume that political change has taken place which permits the adoption of a very different style or model of development from that which could be called the dependent capitalist model. Among the objectives pursued would be the satisfaction of the basic needs of the population, disengagement from the world capitalist economy, massive redistribution of income and wealth, greater collaboration among Third World countries, and the assumption by the State of much greater control over the means of production. ${ }^{5}$ As mentioned, this model has been described as the 'self-reliant' model of growth or as 'collective self-reliance'.

But, as Samir Amin recognised, the experience of the transition to socialism in a country such as the Soviet Union cannot be automatically transferred to the Third World (Amin, 1972). The objective conditions are so different that we are talking about very different processes, and the transition which is most relevant to Third World countries today is one in which countries move from the dependent capitalist model to self-reliant growth, with the eventual transformation of the capitalist mode of production to socialism. Amin argues that the strategies for the transition are, above all, strategies for selfreliance. ${ }^{6}$

Countries which adopt this model will be confronted with a number of conditions that must be considered and dealt with:

1. Serious disruptions could occur due to changes in the sources of supply of materials and consumer goods. This could be due to decisions taken by the dominant colonial or neo-colonial power, as in the case of the Cuban blockade, to internal economic conditions inherent in disengagement from the capitalist economic system, or to a conscious decision by the government.

5 On the self-reliant or collective self-reliant models, see Oteiza and Sercovich, 1976. See also Amin, 1972.

6 Clive Thomas (1974) has recently defined the transition in a similar fashion. 
2. Distortions in the price system will become particularly evident in the first stages of transition. The prevailing price system, which refers to the dependent growth model, will still be affecting resource allocations. This will make changes in the various economic and social policies more difficult, and will necessitate a movement away from the existing price system.

3. Discontinuities will arise in a number of areas: consumption patterns, the provision of social services, organisation of the State bureaucracy and others. The handling of these discontinuities so as to prevent total disintegration in the transition phase becomes of great importance.

4. This is a period of great uncertainty, arising from the factors above, and from the fact that the country is acting in an environment which may be hostile. The reaction of the previously dominant country or countries is an unknown quantity, and the dependent country must gauge very carefully its 'room for manoeuvre'.

5. By its very nature a transition is a stage full of contradictions. Elements of the old order remain, and the new order has not established itself. The State may be completely or partially in the hands of those who seek to transform prevailing conditions, the means of production may not be.

It is apparent then, that this transition phase is a very fragile one, requiring constant attention to the distribution of power, both internal and external, and to creating the conditions that will make the process irreversible. In the management of this delicate phase the role of planning is crucial.

\section{On planning}

Neither capitalist theories of development planning, nor those which come from socialist planners are very useful for planning the transition from dependent to self-reliant growth. Perhaps the name we most associate with development planning is that of Jan Tinbergen. For Tinbergen, planning is a set of procedures related to the preparation of long, medium, and short-term plans. It is also a hierarchical process which goes from the most general (long-term plans) to the most specific (annual plans). His approach to planning has been criticised as unrealistic in view of the absence of technical and human resources in most Third World countries (Leys, 1969; Faber and Seers, eds., 1972). But perhaps the most negative aspect of Tinbergen's approach to planning has to do with his implicit assumption that the prevailing political system is both stable and desirable, and that only tinkering at the margin is required. For hin, the problem is one of maximising the rate of growth of income and achieving maximum efficiency in the utilisation of resources. In a way, planning becomes programming.

The work of socialist planners like Dobb, Lange, Bettelheim, Zielinski, and Kornai is either devoted to planning in a socialist society or, as frequently happens, adopts the language and approaches of orthodox development planning. Lange, for example, has this to say:

The essential (of economic planning) consists in assuring an amount of productive investment which is sufficient to provide for a rise of national income substantially in excess of the rise in population, so that per capita national income increases.

By substantial productive investment I mean investment which is large enough to achieve a breakthrough, or as some economists call it - to produce the 'take-off', the passage from stagnation to intensive development.

(Meier, ed., 1974: 487-8)

There are, of course, differences between socialist and non-socialist planners. One major difference is the emphasis placed by the former on investment in industries which 'produce means of production'. Another has to do with the emphasis on achieving 'material balances', which is characteristic of socialist planning. In general, however, one must look elsewhere for guidance with respect to planning the transition.

The particular structure of planning, its objectives, the variables with which it deals and the strategies adopted are determined by the nature of the system being planned and the environment within which planning takes place. Thus, for example, the degree of control which the State has, or the consensus which exists with respect to national objectives, are important determinants of how planning is organised and of how it operates. The greater the degree of control over the determinants of system behaviour the easier it is for planning to adopt a deterministic posture. The greater the degree of uncertainty or the absence of control over these factors, the more necessary it is for planning to adopt a less deterministic, contingency based approach.

It is important to define the parameters within which planning for the transition begins and which, in some cases, it seeks to modify. These include organisation and functioning of the world economy; the factors affecting the markets for the country's exports; the manner in which the national productive sector is organised and how it relates to the rest of the world; the class 
structure of the country and the manner is which power is allocated and maintained; the resource base, the market size (Vasconi, 1970).

As already mentioned, a primary objective is economic independence or disengagement from the world capitalist system. This means either the closing of the system, or parts of it, or a diversification of sources of supplies or markets (Gutierrez, Ortiz and Villamil, 1971). ${ }^{7}$ A dependent country's economy is characterised by a number of flows such as information, technology, capital, exports, imports and population, over which some measure of control must be achieved. It is essential that the foreign sector, or the channels through which the dependent relationship has been maintained, be given attention by the planning system, so that planning can regulate or control the external links of the country on the basis of overall objectives.

If dependent capitalist growth leads to a particular type of organisation of society's structures, as Osvaldo Sunkel has called it the disintegration of these structures, then planning for self-reliant growth can also be thought of as planning for national integration or reintegration. This process has to be specified in the various contexts: social, cultural, economic and so on. Thus, in economic terms it may mean substituting internal for external linkages (Raj, 1975); in social and cultural terms it may mean dealing with variables related to language policy, the replacement of the previous bureaucratic structures (particularly important in recently independent nations), cultural policy and other such measures aimed at maintaining the country as an integrated whole (Scott, 1970). Obviously, what the specific measures are, and how planning is brought to bear on the problem of national integration will depend on the particular conditions of the countries. In some cases, the priorities may lie in the establishment of a national cultural policy aimed at creating a "feeling of nationhood", as Myrdal has called it. In other cases, priorities may be related to achieving selfsufficiency in food, in some manufactured goods, and in generating industrial linkages. In yet other countries where the first two sets of problems are not critical, planning for national integration may be aimed at, for example, minimising external dependence on technology.

This brings up new considerations related to planning strategies. Planning must be conceived of as a set of temporally linked actions leading to a desired end state, where each decision is

7 For the experience of Tanzania in diversifying its sources of aid, see Green (1972). aimed at making the process of national integration, or the transition, less reversible. Indeed, one important criterion for planning decisions is the extent to which they make it harder to reverse the process.

This requires dealing not only with material conditions, but also with ideological conditions: with information flows and super-structural arrangements which become crucial at least in some phases of the transition.

One consequence of insertion into the world capitalist system is that the criteria used to evaluate behaviour in many areas are those of the dominant countries. This is true in the professions, in making investment decisions, in the organisation and functioning of the educational system, in how the bureaucracy works, and in several other fields. One important objective in the planning of the national re-integration process, then, is that of negating, at least in some important aspects, the cultural influence of the dominant nation or nations.

One set of problems which is important in defining a planning strategy stems from two closely related but partially contradictory requirements: the need to utilise planning as a means of social mobilisation; and the definition of the optimum regime or optimum organisation for the planning system. There is no question but that planning both requires a certain amount of popular support and is an important means of generating it. The problem is that the use of planning as an instrument of social mobilisation may conflict with the optimum organisation for planning in a context such as we have been discussing. Decentralisation may, for example, affect the planning system's capacity to deal with the process of structural transformation as a whole and with the complex web of interrelationships involved. Thus, one could argue that those aspects which directly relate to a country's external links must be centralised. Of course, what is centralised and what is decentralised will depend on the priorities pursued, the environment within which the process takes place and the stage at which the country finds itself. Thus, initially, planning activities could be highly centralised but as the process stabilises, or strengthens, more and more activities can be decentralised. Again, as external constraints are reduced, the need to centralise planning could be reduced. Although it is beyond the scope of this paper to go into this question in detail, it deserves further study.

One consequence of having adopted neo-classical models as the basis for planning was the absence of any attention paid to the demand or con- 
sumption aspects. ${ }^{8}$ Yet it is important to deal with consumption during the transition for a number of reasons: by changing the pattern of consumption, possibilities are opened up for the use of alternative technologies (Raj, 1975), and for the creation of internal linkages and the reduction of imports. Thomas (1974) argues that in the transition there are two "iron laws" of transformation: converging resource use and demand, and converging needs and demand. Obviously, there are constraints to achieving this (the small size of a country being one). But it is important to alter a consumption structure which, in satisfying the needs of a small, high income bourgeoisie, creates serious distortions in the way resources are used. If one of the objectives is to satisfy the basic needs of the population, then planning must deal directly with the structure of consumption. This is particularly true where the market mechanism and the price system are still enforcing the rules of dependent capitalism.

Planners are faced with a great deal of uncertainty, both because they do not control crucial variables and because they are not able to gauge the reactions of other countries. This means that the planning process must adopt a flexible posture, based on contingency planning. There is little use in drawing up very detailed, specific plans: they absorb a great deal of manpower and usually take so long to prepare that their value is limited. Rather, planning must identify strategic variables which are central to the behaviour of the system, and concentrate on them. In addition, planning in the initial stages must be seen as a 'game' in which risk is given explicit attention. It must be strategic, emphasising policies rather than detailed programming. In an environment characterised by a great deal of uncertainty, one way of reducing this uncertainty is to gather external intelligence in order to increase the information on how the world economic system functions and how particular actors in it, such as the multinationals, conduct their operations.

8 Both Lefeber and Thomas discuss the need to consider explicitly in planning the pattem or structure of consumption.

\section{References}

Amin, Samir, 1972, 'Le modèle theorique d'accumulation et de développment dans le monde contemporaine. La problematique de transition', Tiers Monde, No. 52, 10/12

Bettelheim, 1974, La Transición a la Economía Socialista, Editorial Fontanella, Barcelona, (translated from the French, La transition vers l'économie socialiste, Maspero, Paris, 1968)
Cardoso, F. H., 1977, 'El Consumo de la Teoría Sobre la Dependencia en los Estados Unidos', El Trimestre Económico, Enero-Marzo, Num. 173

Gutierrez, E., H. Ortiz and J. Villamíl, 1971, 'Open Systems Planning', Northeast Regional Science Review, Vol I, April

Faber, M. and D. Seers (eds), 1972, Crisis in Planning, Vol I, Chatto and Windus, London

Fajnzyeber, F., 1976, 'Las Empresas Transnacionales y el "Collective Self-Reliance", El Trimestre Económico, Mexico, Oct-Dic no 172

Green, R. H., 1972, 'Some Problems of National Development Planning and Foreign Financing', in S. P. Schatz (ed), South of the Sahara: Development in African Economies, Macmillan, London

Leys, Colin, 1969, 'The Analysis of Planning', in Colin Leys (ed), Politics and Change in Developing Countries, Cambridge University Press, London

Lefeber, Louis, 1974, 'Critique of Development Planning', Indian Economic Review, Vol IX (new series), October

Meier, G. M. (ed), 1974, Leading Issues in Development Economics, Oxford University Press, New York

Oteiza, E. and F. Sercovich, 1976, 'La Confianza Colectiva. Algunos Temas Viejos y Nuevos', El Trimestre Económico, Mexico, Oct-Dic, no 172

Raj, K. N., 1975, 'Linkages in Industrialisation and Development Strategy: Some Basic Issues', Journal of Development Planning, No 8

Scott, R., 1970, 'The Politics of New States: A General Review', in R. Scott (ed), The Politics of New States, George Allen and Unwin, London

Sunkel, Osvaldo, 1971, 'Capitalismo Transnacional y Desintegración Nacional en America Latina', Estudios Internacionales, año IV, num. 16, enero-marzo

Thomas, Clive, 1974, Dependence and Transformation: The Economics of the Transition to Socialism, Monthly Review Press, New York

Vasconi, Tomás, 1970, 'De le Dependencia Como una Categoriá Basica para el Análisis del Desarrollo Latinoamericano', Cuadernos de la Sociedad Venezolana de Planificación, Nums. 82-83, Nov-Dic 